\title{
Monostromatic green algae (Ulvales, Chlorophyta) of São Paulo and Paraná states (Brazil): distribution, growth, and reproduction
}

\author{
MARIA DO ROSÁRIO DE A. BRAGA ${ }^{1}$, MUTUE T. FUJII ${ }^{2}$ and MARILZA CORDEIRO-MARINO²
}

(recebido em 07/03/96; aceito em 04/03/97)

\begin{abstract}
Monostromatic green algae (Ulvales, Chlorophyta) of São Paulo and Paraná states (Brazil): distribution, growth, and reproduction). Culture studies were used for taxa identification and to understand aspects of the biology and physiology of monostromatic green blades growing in various sites along the coast of São Paulo state $\left(23^{\circ} 30^{\prime}-25^{\circ} 12^{\prime} S\right.$, $\left.45^{\circ} 10^{\prime}-48^{\circ} \mathrm{W}\right)$ and one site in Paraná state $\left(25^{\circ} 35^{\prime} \mathrm{S}, 48^{\circ} 21^{\prime} \mathrm{W}\right)$, southeast and south Brazil, respectively. Possible variations of the growth rate, age of reproduction and life history were tested under different conditions of temperature, salinity and day length. Two species were found: Ulvaria oxysperma (Kützing) Bliding and Monostroma sp. The first one has been previously reported for many temperate and tropical estuaries around the world. Green monostromatic blades with the same life-history and ontogeny as Monostroma sp. have been reported so far only for the tropical coast of Brazil. Species are distinct in their ontogeny of the thallus (constant under different conditions) and limiting temperatures of survival. $U$. oxysperma grows and reproduces from 10 to $25^{\circ} \mathrm{C}$ and dies when maintained at $30^{\circ} \mathrm{C}$; Monostroma sp. does not reproduce at $15^{\circ} \mathrm{C}$ and survives at $30^{\circ} \mathrm{C}$. The different salinities and day lengths that were tested had no significant effect on either species.
\end{abstract}

RESUMO - (Algas verdes monostromáticas (Ulvales, Chlorophyta) dos estados de São Paulo e Paraná (Brasil): distribuição, crescimento e reprodução). Estudos em cultura foram usados para identificação de táxons e elucidação de aspectos da biologia e fisiologia de clorofíceas monostromáticas que crescem em vários locais ao longo da costa do estado de São Paulo (23 $30^{\circ}-25^{\circ} 12^{\prime} \mathrm{S}$, $\left.45^{\circ} 10^{\prime}-48^{\circ} \mathrm{W}\right)$ e em um local no estado do Paraná $\left(25^{\circ} 35^{\prime} \mathrm{S}, 48^{\circ} 21^{\prime} \mathrm{W}\right)$, regiões sudeste e sul do Brasil, respectivamente. Possíveis variações na taxa de crescimento, idade de reprodução e histórico de vida foram testadas sob diferentes condições de temperatura, salinidade e comprimento do dia. Foram encontradas duas espécies: Ulvaria oxysperma (Kützing) Bliding e Monostroma sp.. A primeira foi anteriormente reportada para muitos estuários temperados e tropicais, em vários países. Lâminas verdes monostromáticas com a mesma ontogenia e histórico de vida de Monostroma sp. foram reportadas até agora apenas para a costa tropical do Brasil. As espécies são distintas na sua ontogenia do talo (constante sob diferentes condições) e temperatura limite de sobrevivência. $U$. oxysperma cresce e se reproduz de 10 a $25^{\circ} \mathrm{C}$ e morre se mantida a $30^{\circ} \mathrm{C}$; Monostroma sp. não se reproduz a $15^{\circ} \mathrm{C}$ e sobrevive a $30^{\circ} \mathrm{C}$. As diferentes salinidades e comprimentos de dia que foram testados não tiveram efeito significante sobre nenhuma das duas espécies.

Key words - Ulvaria, Monostroma, growth rate, reproduction

\section{Introduction}

Monostromatic green blades, the edible "hitoegusa" (of the Japanese) or Monostroma Thuret (sensu lato), occur all along the coast of Brazil (Oliveira 1977). They mainly grow at river mouths and estuaries but are also found on some rocky coasts. Species and genera of monostromatic Chlorophyta can be separated by differences in their life-history, frond ontogeny and type of swarmer liberation (e.g. Tanner 1981). In Brazil, only plants from the coast of Espírito Santo state $\left(20^{\circ} 04^{\prime} \mathrm{S}\right.$ to $\left.21^{\circ} 13^{\prime} \mathrm{S}\right)$ have previously been identified based on culture studies and they were considered a new species of Monostroma (Cordeiro-Marino et al. 1993). Ulvaria oxysperma (Kützing) Bliding has been reported to São Paulo

1. Estrada Dom Joaquim Mamede 8, 20241-390 Rio de Janeiro, RJ, Brasil.

2. Instituto de Botânica, Caixa Postal 4005, 01061-970 São Paulo, SP, Brasil. and Paraná states (Joly 1951, 1957, 1965, Ugadim 1973), based only on the morphology of the adult plants found in the field.

In Japan many species of Monostroma are used as an important source of food (Kida 1990) and they are among the largest crop of cultivated seaweeds. Species of green monostromatic blades are also consumed in China and other countries of Asia (Tseng 1981) and by local populations along the Pacific Coast of America (Fralick \& Ryther 1976, Acosta 1977). In Brazil, they are only used as food by descendents of asiatic immigrants. Occasionally some of these people exploit natural beds of "hitoegusa" in the southern region of São Paulo state. However, this source of calcium and phosphorus (Arasaki \& Arasaki 1983) and vitamins $B_{1}$ and $C$ (Levring et al. 1969, Nisizawa 1979) remains poorly used in South America.

In this work, life histories and ontogeny of monostromatic green blades were used to investigate their distribution in the southeast and south regions of Brazil. We intended to asses the effects of salinity, 
temperature and day length on the growth and reproduction of these plants to provide basic information on their biology, aiming at an eventual cultivation.

\section{Material and methods}

Unialgal cultures were established from collections made at various sites in São Paulo state and one site in Paraná state (figure 1, table 1), from 1982 to 1992. Unialgal cultures were started as described in Cordeiro-Marino et at. (1993). After 15-30 days from swarmer releasing, groups of five germlings, measuring $0.3-1.5 \mathrm{~mm}$ in diameter, were transferred into $175 \mathrm{ml}$ glass vials with $1 / 2$ strength PES medium (McLachlan 1973). Flasks were maintained in growth chambers with photon flux density of $35-90 \mu \mathrm{mol} . \mathrm{m}^{-2} \cdot \mathrm{s}^{-1}$. Plants were observed and measured approximately every fifteen days when medium was changed. In some cases isolates were followed for 2-5 generations. The desired salinity and the control of contaminants were achieved as described in Cordeiro-Marino et al. (1993). Specimens from which the fragments were obtained for culture were deposited at the "Herbário Científico M. Eneyda P. Kauffmann Fidalgo" of the Instituto de Botânica (SP).

Two different procedures were used to measure the growth rate of the plants. The first block of cultures included two day lengths, four temperatures, and three salinities in different combinations, in a non-orthogonal design:

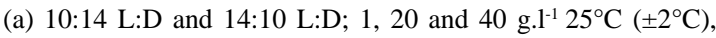
isolates from sites $1,3,4$, and 9;

(b) 14:10 L:D; 1,20 and 40 g. $1^{-1} ; 20$ or $25^{\circ} \mathrm{C}\left( \pm 2^{\circ} \mathrm{C}\right)$, isolates from all sites;

(c) 14:10 L:D; 20 g. $1^{-1} ; 10,20,25$ and $30^{\circ} \mathrm{C}\left( \pm 2^{\circ} \mathrm{C}\right)$, isolates from sites $1,3,4,6$, and 11 (table 1 ).

In this block, growth rate $(\mathrm{R})$ was calculated using variation in the largest diameter of five plants growing in the same flask during two consecutives observations made in the second month after germination, as follows:

$\mathrm{R}=\log \left\{\left[\left(\mathrm{D}_{12}+\mathrm{d}_{12}\right) / 2-\left(\mathrm{D}_{\mathrm{t1}}+\mathrm{d}_{\mathrm{t} 1}\right) / 2\right]\right\} /\left(\mathrm{t}_{2}-\mathrm{t}_{1}\right)$

where: $\mathrm{D}=$ the largest diameter measured in the group; $\mathrm{d}=$ the smallest diameter measured in the group of five plants.

The relationships between $\mathrm{R}$ and temperature, salinity and day length were analysed using one-way or three-way ANOVA. The difference between means was tested by parametric statistics when Bartlett's Test allowed, or by the non-parametric Mann-Whitney U test. As the experiments were not orthogonally designed some combinations of conditions had to be made in order for them to be analysed as specified in the text. Cultures were not replicated; cultures from different sites were used as statistical replicates.

In the other block of experiments the growth rate was measured by using the wet weight (W) of each group of five plants (or the ones that remained alive). Germlings isolated from populations from Perequê River $(50 \mathrm{~m}$ upstream) and Sítio Grande River (at the mouth), Cananéia county, SP (figure 1, sites 7 and 8 ) were used for experiments in factorial design. Three salinities $(1,20$ and 40 g. $\left.1^{-1}\right)$ and four temperatures $\left(15,20,25\right.$ and $\left.30 \pm 2^{\circ} \mathrm{C}\right)$ were tested twice for the two populations, at 14:10 L:D.

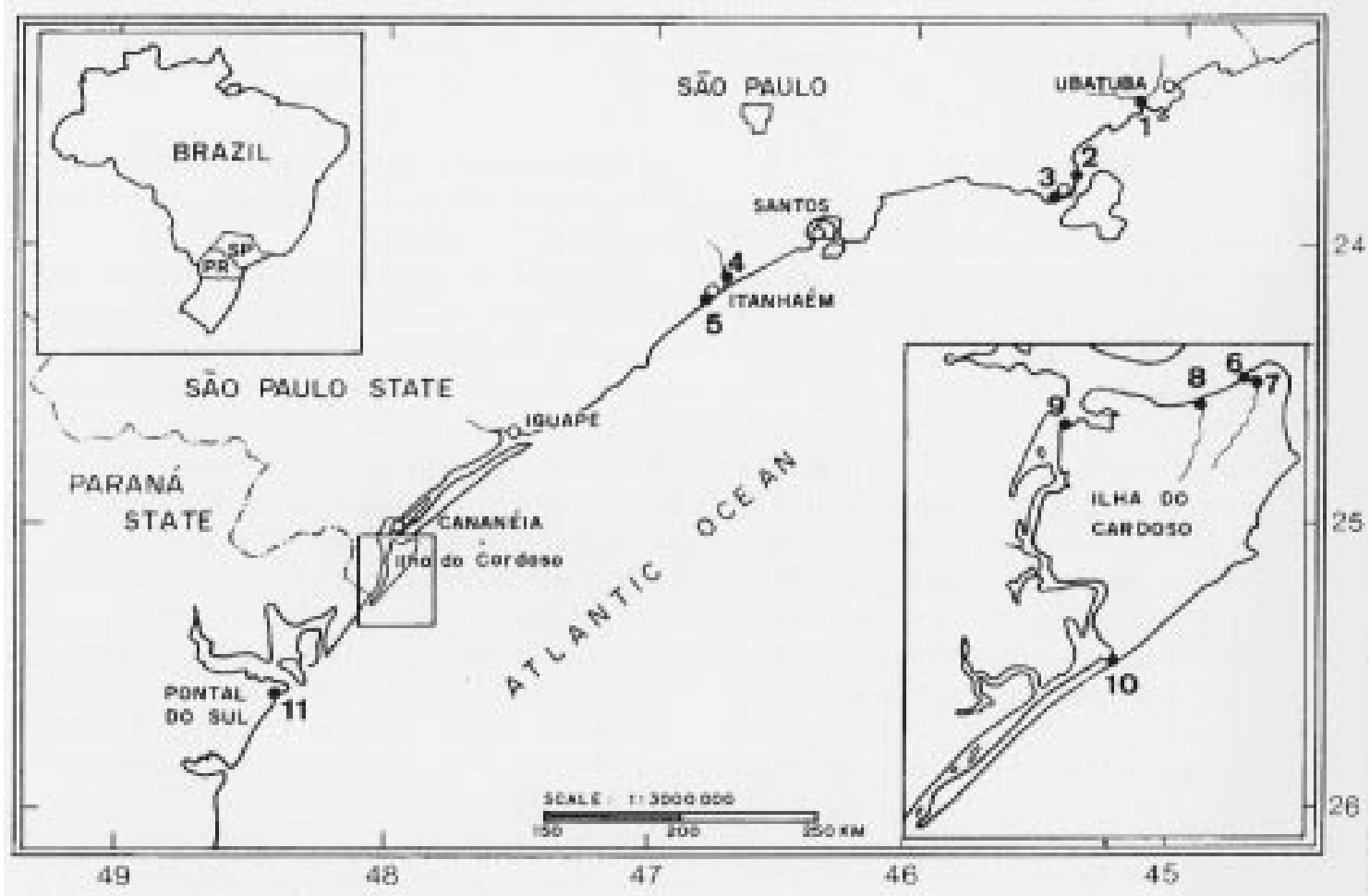

Figure 1. Map of part of São Paulo and Paraná states showing collecting sites (numbers correspond to site names in table 1). 
The growth rate $(\mathrm{R})$ was calculated for measurements made in the second month after germination, as following: $\mathrm{R}=\log \left[\left(\mathrm{W}_{\mathrm{t} 2}-\mathrm{W}_{\mathrm{t} 1}\right) /\left(\mathrm{t}_{2}-\mathrm{t}_{1}\right)\right]$

It was analysed using three-way ANOVA without replicates (salinity $\mathrm{x}$ temperature $\mathrm{x}$ experiment). The difference between means was examined by Student-Newman-Keuls test $(\mathrm{P}<0.05)$.

In both blocks of experiments the relationship between temperature, salinity and first day of reproduction was tested using Kruskal-Wallis test $(\mathrm{P}<0.05)$. The age of reproduction was arbitrarily ranked for the purposes of the analysis: (a) reproduction before 60 days; (b) reproduction after 60 days; (c) no reproduction observed, and (d) plants died.

\section{Results}

Life-history, bladeontogeny, and distribution - Two species of monostromatic green blades occurred in the area sampled and they were characterized by two different types of bladeontogeny (figure 2). All isolates presented an asexual life-history without alternation of phases (figure 2). Bi-flagelate cells were released one after the other through an opening in the cell wall and they did not fuse. These characteristics remained constant under all tested conditions. Plants that developed into a tubular germling before opening to form a blade correspond to Ulvaria oxysperma (Kützing) Bliding. The ones forming a blade directly are referred to as Monostroma sp. Both species occur in the sampled area and can grow at places where there is direct discharge of freshwater (table 1), but only Monostroma sp. was collected from exposed seashores. There was no indication of preference for season or substrate (table 1).

Growth - (a) Diameter: when plants were growing at salinity of $20 \mathrm{~g} .1^{-1}$ the effect of temperature $(10,20$, 25 and $30^{\circ} \mathrm{C}$ ) on the growth rate was different for the two species (figure 3). Ulvaria oxysperma showed no significant differences in growth rate at different temperatures (one-way ANOVA, $\mathrm{P}=0.196$ ). For Monostroma sp. only growth rate at $10^{\circ} \mathrm{C}$ was significantly lower than at 20,25 and $30^{\circ} \mathrm{C}$ (Kruskal-Wallis test: $\mathrm{P}=0.0$ 17; Mann-Whitney U

Table 1. Collection sites (*estuaries) in São Paulo and Paraná states, dates, number of isolates, substrate where plants were growing and type of germination: (a) Ulvaria oxysperma or tube and (b) Monostroma sp. or blade. (For location see numbers on map).

\begin{tabular}{|c|c|c|c|c|}
\hline Site & Date of sampling & Number of cultures & Type of substrate & Type of germination \\
\hline \multirow[t]{7}{*}{ (1) Claro and Escuro Rivers* } & $04 / \mathrm{vii} / 85$ & 04 & pneumatophore & $\mathrm{a}$ \\
\hline & 04/vii/85 & 01 & sediment & $\mathrm{b}$ \\
\hline & 27/viii/85 & 03 & branch & $\mathrm{b}$ \\
\hline & 12/iii/86 & 01 & sediment & $\mathrm{b}$ \\
\hline & 10/iv/86 & 01 & pneumatophore & $\mathrm{a}$ \\
\hline & 10/iv/86 & 01 & sediment & $\mathrm{b}$ \\
\hline & 27/vii/87 & 01 & sediment & $\mathrm{a}$ \\
\hline \multirow[t]{2}{*}{ (2) São Francisco Cove } & $06 / x / 86$ & 01 & boulder & $\mathrm{b}$ \\
\hline & $27 / v i / 87$ & 01 & boulder & $\mathrm{b}$ \\
\hline \multirow[t]{3}{*}{ (3) Araçá Beach } & 04/vii/85 & 02 & pneumatophore & $\mathrm{b}$ \\
\hline & 27/ix/85 & 01 & pneumatophore & $\mathrm{b}$ \\
\hline & $12 / \mathrm{iii} / 86$ & 01 & pneumatophore & $\mathrm{b}$ \\
\hline \multirow[t]{5}{*}{ (4) Itanhaém River* } & $14 / v i / 82$ & 01 & pneumatophore & $\mathrm{a}$ \\
\hline & 04/vi/85 & 05 & pneumatophore & $\mathrm{a}$ \\
\hline & $11 / v / 86$ & 02 & pneumatophore & a \\
\hline & $25 / x / 92$ & 01 & pneumatophore & $\mathrm{a}$ \\
\hline & $25 / x / 92$ & 02 & boulder & $\mathrm{b}$ \\
\hline \multirow[t]{2}{*}{ (5) Cibratel Beach } & $15 /$ viii/85 & 01 & rocky shore & $\mathrm{b}$ \\
\hline & $11 / v / 86$ & 02 & rocky sbore & $\mathrm{b}$ \\
\hline \multirow[t]{2}{*}{ (6) Pereirinha Beach* } & $12 / \mathrm{vi} / 86$ & 01 & boulder & $\mathrm{b}$ \\
\hline & $15 / v i / 88$ & 02 & boulder & $\mathrm{b}$ \\
\hline (7) Perequê River* & 17/viii/88 & 03 & branch & $\mathrm{b}$ \\
\hline \multirow[t]{4}{*}{ (8) Sítio Grande River* } & 25/viii/87 & 03 & branch & $\mathrm{a}$ \\
\hline & 25/viii/87 & 01 & sediment & a \\
\hline & 14/vi/88 & 02 & branch & $\mathrm{b}$ \\
\hline & 06/xii/88 & 01 & branch & $\mathrm{b}$ \\
\hline (9) Casca lsland & 04/ix/86 & 02 & branch & $\mathrm{b}$ \\
\hline (10) Marujá Beach & 04/ix/86 & 02 & branch & $\mathrm{b}$ \\
\hline (11) Perequê Tidal Creek* & 1 2/viii/87 & 03 & pneumatophore & $\mathrm{a}$ \\
\hline
\end{tabular}


test betwenn $10^{\circ} \mathrm{C}$ and other temperatures: $\mathrm{P}=0.02$ ). At the intermediate temperatures of 20 and $25^{\circ} \mathrm{C}$, no significant differences were observed when plants were growing at 1,20 and 40 g. $1^{-1}$, for Ulvaria oxysperma (one-way ANOVA, P > 0.05) and for Monostroma sp. (one-way ANO VA, P>0.05).

For day length, a three-way ANOVA including salinity (1, 20 and 40 g. $1^{-1}$ ), experiment (three experiments with Ulvaria oxysperma and four with Monostroma sp.), and their interactions, showed no significant effect $(\mathrm{P}>0.05)$ of these parameters on the growth rate of either species, when submitted to a temperature of $25^{\circ} \mathrm{C}$.

b) Weight: the two isolates from Sítio Grande River were $U$. oxysperma and the ones from Perequê River were Monostroma sp. The growth rate was calculated for two observations made during the second month after germination. In $92 \%$ of the times the growth rate was larger in the period around 30-45 days $\left(R_{1}\right)$ than in the next 15 days $\left(R_{2}\right)$ (table 2 ).

Table 2. Growth rates based on wet weight $\left(\mathrm{R}_{1}=\right.$ between $30-45$ th and $\mathrm{R}_{2}=$ between $45-60$ th days after germination $)$ and survival days and age (in days) of plants when first reproducing occurred for (1) Ulvaria oxysperma and (2) Monostroma sp. at different salinities and temperature; (-) plants died.

\begin{tabular}{|c|c|c|c|c|c|c|}
\hline Species & $\begin{array}{l}\text { Salinity } \\
\left(\mathrm{g} . \mathrm{l}^{-1}\right)\end{array}$ & $\begin{array}{c}\text { Temperature } \\
\left({ }^{\circ} \mathrm{C}\right)\end{array}$ & Experiment & $\begin{array}{c}\mathrm{R}_{1} \\
\left(\text { day }^{-1}\right)\end{array}$ & $\begin{array}{c}\mathrm{R}_{2} \\
\left(\text { day }^{-1}\right)\end{array}$ & $\begin{array}{l}\text { Reproduction or } \\
\text { survival (days) }\end{array}$ \\
\hline 1 & 1 & 15 & 1 & 0.135 & 0.078 & 43 \\
\hline 1 & 1 & 15 & 2 & 0.142 & 0.105 & 45 \\
\hline 1 & 1 & 20 & 1 & 0.131 & 0.057 & 43 \\
\hline 1 & 1 & 20 & 2 & 0.175 & 0.010 & 45 \\
\hline 1 & 1 & 25 & 1 & 0.100 & 0.064 & 30 \\
\hline 1 & 1 & 25 & 2 & 0.175 & 0.016 & 45 \\
\hline 1 & 1 & 30 & 1 & 0.100 & 0.012 & $(-)$ \\
\hline 1 & 1 & 30 & 2 & 0.020 & 0 & $(-)$ \\
\hline 1 & 20 & 15 & 1 & 0.113 & 0.097 & 30 \\
\hline 1 & 20 & 15 & 2 & 0.204 & 0.091 & $(78)^{*}$ \\
\hline 1 & 20 & 20 & 1 & 0.096 & 0.077 & 30 \\
\hline 1 & 20 & 20 & 2 & 0.095 & 0.077 & 30 \\
\hline 1 & 20 & 25 & 1 & 0.131 & -0.049 & 30 \\
\hline 1 & 20 & 25 & 2 & 0.203 & -0.059 & 30 \\
\hline 1 & 20 & 30 & 1 & 0.091 & 0.075 & 30 \\
\hline 1 & 20 & 30 & 2 & 0.107 & 0.067 & $(-)$ \\
\hline 1 & 40 & 15 & 1 & 0.085 & 0.150 & 30 \\
\hline 1 & 40 & 15 & 2 & 0.103 & 0.140 & $(75)^{*}$ \\
\hline 1 & 40 & 20 & 1 & 0.132 & -0.037 & 30 \\
\hline 1 & 40 & 20 & 2 & 0.188 & 0.135 & 45 \\
\hline 1 & 40 & 25 & 1 & 0.227 & 0.085 & 30 \\
\hline 1 & 40 & 25 & 2 & 0.204 & -0.010 & 45 \\
\hline 1 & 40 & 30 & 1 & 0.103 & 0.090 & $(75)^{*}$ \\
\hline 1 & 40 & 30 & 2 & 0.086 & 0.046 & $(-)$ \\
\hline 2 & 1 & 15 & 1 & 0.136 & 0.066 & $(90)^{*}$ \\
\hline 2 & 1 & 15 & 2 & 0.130 & 0.084 & $(100)^{*}$ \\
\hline 2 & 1 & 20 & 1 & 0.130 & 0.055 & 90 \\
\hline 2 & 1 & 20 & 2 & 0.117 & 0.080 & $(100)^{*}$ \\
\hline 2 & 1 & 25 & 1 & 0.131 & 0.032 & $(90)^{*}$ \\
\hline 2 & 1 & 25 & 2 & 0.076 & 0.073 & 30 \\
\hline 2 & 1 & 30 & 1 & 0.138 & 0.075 & $(90)^{*}$ \\
\hline 2 & 1 & 30 & 2 & 0.092 & 0.071 & 47 \\
\hline 2 & 20 & 15 & 1 & 0.179 & 0.057 & $(90)^{*}$ \\
\hline 2 & 20 & 15 & 2 & 0.160 & 0.102 & $(100)^{*}$ \\
\hline 2 & 20 & 20 & 1 & 0.153 & 0.041 & 90 \\
\hline 2 & 20 & 20 & 2 & 0.113 & 0.040 & 30 \\
\hline 2 & 20 & 25 & 1 & 0.130 & -0.034 & 30 \\
\hline 2 & 20 & 25 & 2 & 0.073 & -0.043 & 30 \\
\hline 2 & 20 & 30 & 1 & 0.120 & -0.035 & 30 \\
\hline 2 & 20 & 30 & 2 & 0.093 & 0.057 & 30 \\
\hline 2 & 40 & 15 & 1 & 0.141 & 0.075 & $(75)^{*}$ \\
\hline 2 & 40 & 15 & 2 & 0.126 & 0.153 & $(100)^{*}$ \\
\hline 2 & 40 & 20 & 1 & 0.195 & 0.080 & $(70)^{*}$ \\
\hline 2 & 40 & 20 & 2 & 0.083 & 0.086 & $(100)^{*}$ \\
\hline 2 & 40 & 25 & 1 & 0.168 & 0.038 & 30 \\
\hline 2 & 40 & 25 & 2 & 0.132 & 0.044 & 30 \\
\hline 2 & 40 & 30 & 1 & 0.147 & 0.060 & 57 \\
\hline 2 & 40 & 30 & 1 & 0.143 & 0.061 & 30 \\
\hline
\end{tabular}

( )* no swarmers released before the end of the experiment. 
Table 3 - Three-way ANOVA for growth rate from 30-40th day of culture, with salinity $\left(1,20\right.$ and 40 g. $\left.1^{-1}\right)$ temperature $\left(15,20,25\right.$ and $\left.30^{\circ} \mathrm{C}\right)$ and experiments $(\mathrm{n}=2)$. Grouping means by temperature for Ulvaria oxysperma by Student Newman-Keuls test: $\underline{252015} \underline{30}{ }^{\circ} \mathrm{C}(\mathrm{P}<0.05)$.

\begin{tabular}{ccccc}
\hline Species & Salinity & Temperature & Experiment & Interactions \\
\hline U. oxysperma & $\mathrm{ns}$ & $\mathrm{P}=0.022$ & $\mathrm{~ns}$ & $\mathrm{~ns}$ \\
Monostroma $\mathrm{sp}$ s. & $\mathrm{ns}$ & $\mathrm{ns}$ & $\mathrm{P}=0.008$ & $\mathrm{~ns}$ \\
\hline
\end{tabular}

Table 4. Kruskal-Wallis one-way ANOVA to test possible relations between temperature $\left(15,20,25\right.$ and $\left.30^{\circ} \mathrm{C}\right)$ and salinity $(1,20$ and 40 g. $\left.1^{-1}\right)$ with the first day when reproduction was observed $(\mathrm{P}<0.05)$.

\begin{tabular}{ccc}
\hline Species & Temperature & Salinity \\
\hline U. oxysperma & $\mathrm{P}=0.023$ & $\mathrm{~ns}$ \\
Monostroma sp. & $\mathrm{P}=0.003$ & $\mathrm{~ns}$ \\
\hline
\end{tabular}

Furthermore, at the second observation the growth rale was already decreasing under many conditions due to the fact that plants lose tissue when reproducing. Therefore, $\mathrm{R}_{1}$ (table 2) was used for analysing the effect of salinity and temperature, together with verifying differences between experiments. Growth rates were different between the two experiments with Monostroma sp. (table 3). However, there were no interactions between experiment and either temperature or salinity, and the results of the two experiments were combined in a three-way ANOVA. Of the environmental parameters only temperature exhibited a significant effect on $\mathrm{R}(\mathrm{P}=0.02)$ and only in $U$. oxysperma. The

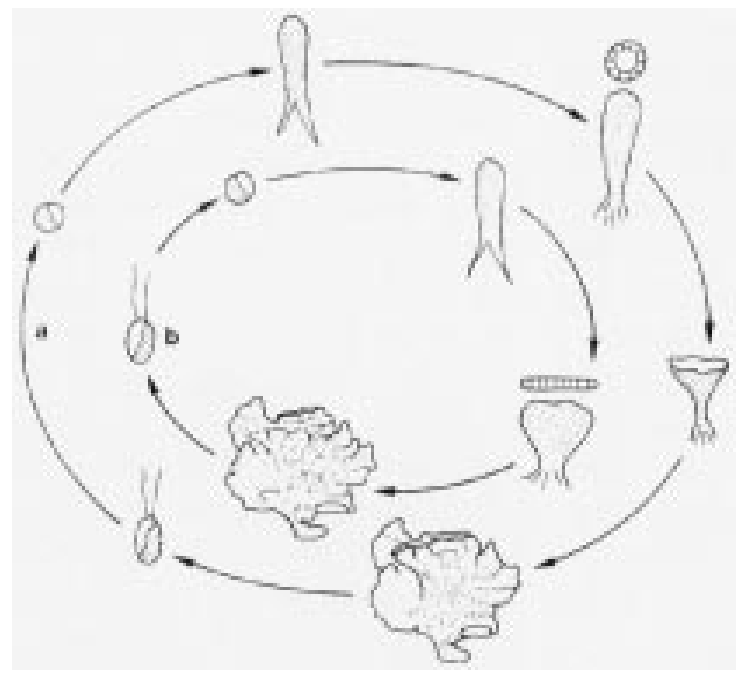

Figure 2. Life-history and development of the thallus of both species. Direct development gives rise first to a hollow sac in (a) Ulvaria oxysperma and to a flat blade in (b) Monostroma sp. growth rate was lower at $30^{\circ} \mathrm{C}$ and similar at the other temperatures tested $\left(15,20\right.$, and $\left.25^{\circ} \mathrm{C}\right)$ using Student-Newman-Keuls test.

Reproduction - Only temperature showed a significant effect on the age of reproduction of both species (table 4). Ulvaria oxysperma released swarmers early in the second month after germination at all tested conditions, except at $30^{\circ} \mathrm{C}$. At this temperature plants died or did not reproduce until the 75th day, except in one case in which they reproduced at $30^{\circ} \mathrm{C}$ at $20 \mathrm{~g} .1^{-1}$ (table 2). In one of the experiments plants from Sítio Grande River did not reproduce at $15^{\circ} \mathrm{C}-40 \mathrm{~g} .1^{-1}$ and only late at 20 g. $1^{-1}$ (78th day). The four isolates of Ulvaria oxysperma collected at other sites and grown at $10^{\circ} \mathrm{C}$ reproduced between 50 and 90 days while at $30^{\circ} \mathrm{C}$ they started to die after 50 days. Nevertheless, one isolate of $U$. oxysperma from Itanhaém River growing at $30^{\circ} \mathrm{C}$ reproduced after 70 days.

Although plants of Monostroma sp. from Perequê River did not die under any of the conditions tested, they did not reproduce during the period of observation, when growing at $15^{\circ} \mathrm{C}$ (table 2). At a temperature of $20^{\circ} \mathrm{C}$ this species reproduced at 1 and $20 \mathrm{~g} \cdot 1^{-1}$ of salinity (table 2). Temperatures of 25 and $30^{\circ} \mathrm{C}$ were better for reproduction and release of

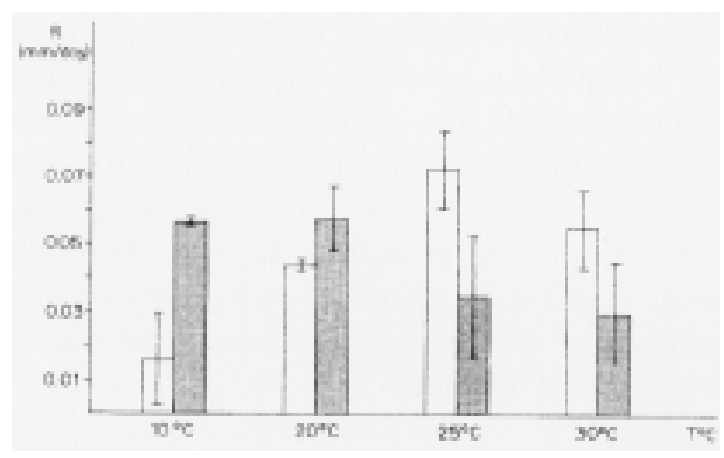

Figure 3. Growth rate of Ulvaria oxysperma $(\square)$ and Monostroma sp. $\left(\square\right.$ growing at salinity of $20 \mathrm{~g} .1^{-1}$ and different temperatures. Growth of groups of five plants measured by differences in diameter. Bars represent standard error, $\mathrm{n}=3$. 
swarmers generally occurred early in the second month after germination but was delayed at $1 \mathrm{~g} \cdot 1^{-1}$ in one of the two experiments (table 2). Observations on plants collected at other sites showed that none of the four isolates of Monostroma sp. cultivated at $10^{\circ} \mathrm{C}-20 \mathrm{~g} \cdot 1^{-1}$ reproduced and they all died after $45-$ 75 days. When grown at $30^{\circ} \mathrm{C}-20 \mathrm{~g} .1^{-1}$ isolates from the same plants reproduced in 50-80 days.

When plants from various places were growing at $25^{\circ} \mathrm{C}$ and $20 \mathrm{~g} .1^{-1}$ of salinity, different day lengths did not make significant difference on the age of reproduction for Monostroma sp. (Mann-Whitney U test, $\mathrm{P}>0.05)$. They reproduced between 45 to 75 days. As for Ulvaria oxysperma when plants were growing at this temperature and salinity, reproduction always occurred between 35 to 45 days. Normally, in culture, plants of both species begin to reproduce when they are $0.5-1.0 \mathrm{~cm}$ (Monostroma sp. can reach $2.0 \mathrm{~cm}$ ) in diameter and they then start to lose cells and disintegrate.

\section{Discussion}

The combinations of ontogeny of the thallus and life history found in cultured plants of the present study correspond to two taxa of monostromatic green blades: Ulvaria oxysperma and Monostroma sp. For the former, these characteristics have already been described by, for example, Bliding (1968) and Tatewaki (1972) but the direct development in blade, together with the lack of alternation of morphological distinct phases observed in the second has been described previously only by Cordeiro-Marino et al. (1993) for specimens of Monostroma from Espírito Santo state, tropical coast of Brazil. Only observations on the development of the various plants collected made it possible to find that two taxa are growing between latitudes $23^{\circ} 30^{\prime}$ and $25^{\circ} 35^{\prime} \mathrm{S}$ on the coast of Brazil. The co-occurrence of the two taxa in some places, together with the great difficulty of recognizing adult plants calls attention, once more, to the necessity of culture studies to identify the species and genera of this group.

Kida (1967) reports the co-occurrence of two species with monostromatic green blades belonging to genus Monostroma growing at Ise Bay, on the temperate coast of Japan, in a similar situation. As in the present study both species were growing at the same time of the year but, at Ise Bay, they occur at different tidal levels. Here, although we do not have information on the exact tidal level where the plants grow, no apparent distinction in their vertical position was verified. In the Southern part of São Paulo state (25'10'S), U. oxysperma and Monostroma sp. were recruited at the same tidal levels on the shore (Braga 1997).

Ulvaria oxysperma has a broad distribution occurring in brackish water in temperate (e.g. Bliding 1968, Tatewaki 1969, Golden \& Garbary 1984) as well as tropical areas (Kapraun \& Flynn 1973). It is not surprising that this species can grow and reproduce in brackish water sites of São Paulo and Paraná states. As a general trend the present results for growth rate and reproduction indicate that a temperature of $30^{\circ} \mathrm{C}$ is the upper limit for the species and some plants die at this temperature (table 2). The minimum temperature limit for the survival of the species is outside the range tested. Tatewaki (1969) cultured this species for many generations at 10 to $14^{\circ} \mathrm{C}$ and plants grew better when submitted to $14^{\circ} \mathrm{C}$.

In Brazil, Monostroma sp. was previously only reported to occur in a tropical region (CordeiroMarino et al. 1993). In the present study the species was found growing in estuaries as well as in the sea. In contrast to Ulvaria oxysperma, it can grow and reproduce at a constant temperature of $30^{\circ} \mathrm{C}$. Monostroma sp. from Espírito Santo state did not reproduce when growing at $30^{\circ} \mathrm{C}-1 \mathrm{~g} .1^{-1}$ (Cordeiro-Marino et al. 1993). In the present study Monostroma sp. showed a minimum temperature limit of reproduction between 15 and $20^{\circ} \mathrm{C}$ confirming results obtained with plants from Espírito Santo state (Cordeiro-Marino et at. 1993).

The fact that the salinities tested had no significant effect on the growth rate and age of reproduction of the two species can explain the cooccurrence of the two species at estuaries and their middle to high intertidal vertical position on the shore, where they can be exposed to rain. It can not explain, however, why only Monostroma sp. occurs in rocky shores where there is no freshwater discharge. In contrast to the present results, salinity had a significant effect on the growth rate of Monostroma sp. from Espírito Santo state (Cordeiro-Marino et al. 1993) and this may be an indication of ecotypic differentiation. 
The presence of fertile plants all year around and the lack of seasonality found in the recruitment of the two taxa (Braga 1997) is in accordance with the results that showed that day length (corresponding to the maximum and the minimum in the region) has no marked effect on the growth rate or age of reproduction.

In conclusion, culture procedures showed that two species of morphological similar monostromatic blade-like chlorophytes grow in Southeast and South Brazil. Of the environmental parameters tested (temperature, salinity and day length), only temperature had a clear effect on the growth rate and age of reproduction.

Acknowledgments - We are grateful to Eurico Oliveira, Tim Moulton and Silvia Guimarães for important suggestions, José Domingos and Elizete M. Mitsugui for their help in the field and laboratory, and the Seção de Ilustração of the Instituto de Botânica for the illustrations. This work was partly supported by a grant to the first author by Fundação de Amparo à Pesquisa do Estado de São Paulo (FAPESP Proc. 87/3259-8).

\section{References}

ACOSTA, J.P. 1977. Nombres vulgares y usos de las algas en el Perú. Univ. Nacional Mayor de San Marcos, serie de divulgación 7:1-9.

ARASAKI, S. \& ARASAKI, T. 1983. Vegetables from the sea: to help you look and feel better. Japan Publications, Tokyo.

BLIDING, C. 1968. A critical survey of European taxa in Ulvales: part II - Ulva, Ulvaria, Monostroma, Kornmania. Bot. Notiser 121:535-629.

BRAGA, M.R.A. 1997. Recruitment of two species of monostromatic blade-like chlorophytes, Monostroma sp. and Ulvaria oxysperma (Chlorophyta) in São Paulo State, Brazil. Phycol. Res. 45:153-161.

CORDEIRO-MARINO, M., BRAGA, M.R.A., FUJII, M.T., GUIMARÃES, S.M.P.B. \& MITSUGUI, E. 1993.

Monostromatic green algae from Espírito Santo State, Brazil: life-history, growth and reproduction in culture. Rev. Bras. Biol. 53:285-293.

FRALICK, R.A. \& RYTHER, J.H. 1976. Uses and cultivation of seaweeds. Oceanus 19:1-7.
GOLDEN, L. \& GARBARY, D. 1984. Studies on Monostroma (Monostromataceae, Chlorophyte) in British Columbia with emphasis on spore release. Jap. J. Phycol. 32:293-299.

JOLY, A.B. 1951. Contribuição para o conhecimento da flora algológica marinha do Estado do Paraná. Bol. Inst. Paul. Oceanogr. 2:125-138.

JOLY, A.B. 1957. Contribuição ao conhecimento da flora ficológica marinha da Baía de Santos e arredores. Bolm. Fac. Fil. Ciênc. Univ. São Paulo (bot.) 14:1-196.

JOLY, A.B. 1965. Flora marinha do litoral norte do Estado de São Paulo e regiões circunvizinhas. Bolm. Fac. Fil. Ciênc. Univ. São Paulo (bot.) 21:1-393.

KAPRAUN, D.F. \& FLYNN, E.H. 1973. Culture studies of Enteromorpha linza (L.) J.Ag. and Ulvaria oxysperma (Kütz.) Bliding (Chlorophyceae, Ulvales) from Central America. Phycologia 12:145-152.

KIDA, W. 1967. Studies on the morphology and ecology of Monostroma in Ise Bay and vicinity, Japan. J. Fac. Fish. Pref. Univ. Mie 7:82-159.

KIDA, W. 1990. Culture of seaweeds Monostroma. Mar. Behav. Physiol. 16:109-131.

LEVRING, T., HOPPE, H.A. \& SCHMID, O.J. 1969. Marine algae: a survey of research and utilization. Cram, de Gruyter, Hamburg.

McLACHLAN, J. 1973. Growth media marine. In Handbook of phycological methods: culture methods and growth measurements (J.R. Stein, ed). Cambridge Univ. Press, Cambridge,p. 25-51.

NISIZAWA, K. 1979. Pharmaceutical studies on marine algae in Japan. In Marine algae in pharmaceutical science (H.A. Hope, T. Levring \& Y. Tanaka, eds). Walter de Gruyter, New York, p.243-264.

OLIVEIRA, E.C. 1977. Algas marinhas bentônicas do Brasil. Tese de livre docência, Universidade de São Paulo, São Paulo.

TANNER, C.E. 1981. Chlorophyta: life histories. In The biology of seaweeds (C.S. Lobban \& M.J. Wynne, eds). Blackwell Scientific Publ., Oxford, p.218-247.

TATEWAKI, M. 1969. Culture studies on lhe life history of some species of the genus Monostroma. Scient. Pap. Inst. algol. Res. Hokkaido Univ. 6:1-56.

TATEWAKI, M. 1972. Life history and systematics in Monostroma. In Contributions to the systematics of benthic marine algae of the North Pacific (I.A. Abbott \& M. Kurogi, eds). Jap. Soc. Phycology, Kobe, p.1-15.

TSENG, C.K. 1981. Commercial cultivation. In The biology of seaweeds (C.S. Lobban \& M.J. Wynne, eds). Blackwell Scientific Publ, Oxford, p.680-725.

UGADIM, Y. 1973. Algas marinhas bentônicas do litoral sul do Estado de São Paulo e do Estado do Paraná: divisão Chlorophyta. Bolm. Botânica, Univ. S. Paulo 1:11-77. 